\title{
$\mathrm{H}_{2}$ 受容体拮抗薬が有効であった Zollinger-Ellison 症候群の 1 例
}

\author{
西宮市立中央病院外科 \\ 柴田 信博 渡瀬 誠藤本 直樹 \\ 相川隆夫 田村茂行 野口貞夫
}

\section{A CASE REPORT OF EFFECTIVE TREATMENT WITH FAMOTIDINE FOR ZOLLINGER-ELLISON SYNDROME}

\author{
Nobuhiro SHIBATA, Makoto WATASE, Naoki FUJIMOTO, \\ Takao AIKAWA, Shigeyuki TAMURA and Sadao NOGUCHI \\ Dept. Surgery, Nishinomiya Municipal Central Hospital
}

索引用語：Zollinger-Ellison 症候群, $\mathrm{H}_{2}$ 受容体拮抗薬

はじめに

Zollinger-Ellison 症候群 (ZES)の治療では, 畽瘍の コントロールと, 胃酸の過制分泌付するコントロー ルが要求される12). 畽場のコントロールには, さまざ まな理由で限界があるが3 ${ }^{306}$ ，胃酸の過剩分泌に対し ては, 胃全摘により永久的にコントロールされること から, ZESの治療原則は, 最近まで, “腫瘍の摘出と胃 全摘”であっだ2.

しかし， $\mathrm{H}_{2}$ 受容体拮抗薬 $\left(\mathrm{H}_{2}\right.$-blocker $)$ が出現し, ZES の酸分泌抑制の目的で使用されるようになって,

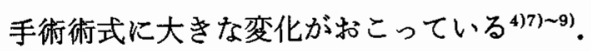

今回, 漫潤・転移のため, 腫愓の摘出が不可能であっ たZESに対し， $\mathrm{H}_{2}$-blockerであるファモチジンの持 続大量投与を行い，十分な胃酸分泌抑制効果の得られ た症例を経験したので報告し，ZES に対する胃全摘の 適応について，若干の文献的考察を加える.

\section{症例}

症例：47歳, 女性. 主婦.

家族歷：特記すべきことなし。

既往歴：特記すべきことなし.

現病歴：昭和 61 年 5 月初旬ごろから，心窝部痛扣よ び呕気が頻回に出現するようになり, その後黒色便に 気付いた。近医を受診し，上部消化管透視および内視 鏡検査により，胃潰瘍と診断され，抗潰瘍剂による内 服治療を行っていた。しかし, 食欲不振, 心窝部不快

$<1987$ 年 6 年 8 日受理 $>$ 別刷請求先 : 柴田 信博

₹663 西宮市林田町 8-24 西宮市立中央病院外科
感が続き，同院にて，3力月後再度内視鏡検查が施行 され，十二指腸潰瘍の診断下に約 1 力月の入院治療を らけた。しかし，症状は軽快せず，食後の呕吐も時に 出現するようになり，昭和61年10月 8 日，当院内科を 受診し,治療目的にて入院した。 5 力月で $8 \mathrm{~kg}$ の体重減 少がある. 全経過を通じて下䦌の訴えなく, 高血厈を 指摘されたこともない。

入院時現症: 身良 $142 \mathrm{~cm}$, 体重 $28.8 \mathrm{~kg}$, 栄養状態は 不良である。血圧 $140 / 80 \mathrm{mmHg}$, 脈拍 $90 /$ 分, 董血, 黄 疸を認めない，碩・頸・胸部に理学的異常所見を認め ず，表在リンパ節も触知しない. 腹部はやや陥凹し, 心窩部に軽度の圧痛と抵抗を認める以外著変を認めな い. 直腸指診でも異常を認めない。

入院時検查成績打上び入院後経過：表 1 に検查成績 を示す，軽度の筫血と低カリウム血症を認める以外，

一般血液検查に異常なし，上部内視鏡検查では，食道 に著変なく，胃体下部から幽門輪に至るまで，胃壁は 浮腫が強くビランが多発していた。 また，十二指腸球 部後壁に巨大な潰瘍を認めた。 入院時から，患者は呕 気, 食欲不振を強く訴兄, 時に胃液様の呕吐もみられ た. シメチジン $600 \mathrm{mg} /$ 日の経静脈投与が行われ，幽門 狭窄の䛦断下に手術目的にて10月14日，外科に紹介さ れた。転科後, 絶食下に高カロリ一輸液を行い, 血清 ガストリンの定量を行ったところ， $982 \mathrm{pg} / \mathrm{ml}$ と異常 高値を呈して打り，ZESを強く疑い精查中であった が，潰瘍底からの大出血のため，10月18日，緊急手術 を余儀なくされた。

手術所見技よび手術術式：全身麻醉下に上正中切開 
表 1 入院時検查成皘

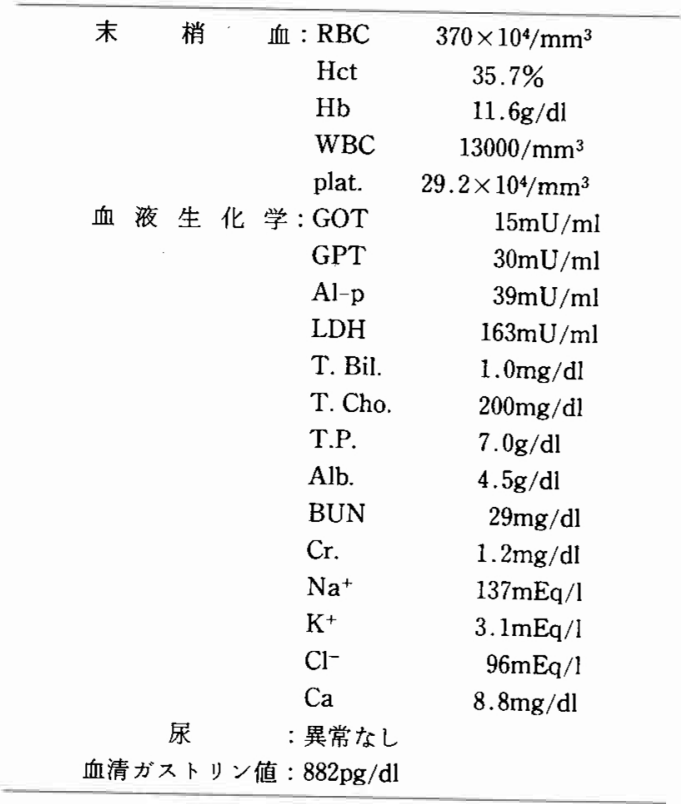

にて開腹した，腹水は認めず，胃幽門側は浮腫状で, 十二指腸球部はさらに強い浮腫, 壁肥厚が認められた。 十二指腸潰瘍は, 球部後壁全域にわたって存在し膵部 へ穿通し，潰瘍底は一部壊死に陥っていた。胃切開に より潰瘍底を露出し, 動脈性出血点 2 力所を縫合止血 した。膵頭部には，手挙大の腫煬があり，これは門脈 および上腸間膜動脈根部から中結腸動脈起部へ浸潤し ていた。 また, 肝外側区域に $3 \mathrm{~mm}$ 大の淡黄色榷様の結 節を認めた。これらの所見から，膵頭部の悪性ガスト リノーマ招よび肝転移と診断した。腫瘍の摘出は不可 能であり, 縫合止血のみでは胃酸分泌穴進に伴う再出 血は必発々考光, 本来なら胃全摘の適応であるが, 全 身状態を考慮し，胃切除術にとどめた。また，十二指 腸断端は, 浮腫が強く, 縫合不全が必発すると考觉ら れたため,コッへルの授動術を行い, 膵頭とともに十 二指腸断端を腹壁創に挙上固定し, catheter duodenostomy を行った，胃空腸吻合にブラウン吻合 を追加して，ウィンスロー孔と肝下面にドレーンを挿 入して手術を終了した。肝転移巣と考えられた結節は, 生検の目的で摘出した。

胃切除標本和よび腫瘍生検所見：胃粘膜は浮腫状 で,ビランが多発している(図 1). 肝腫場の組織像は, 円形ないし類円形の核を有する小型の細胞が微細な間 質を伴いながら，充実結節状の増殖を示している（図
図 1 切除胃標本写真。著しい胃壁の浮腫とビランを 認める.

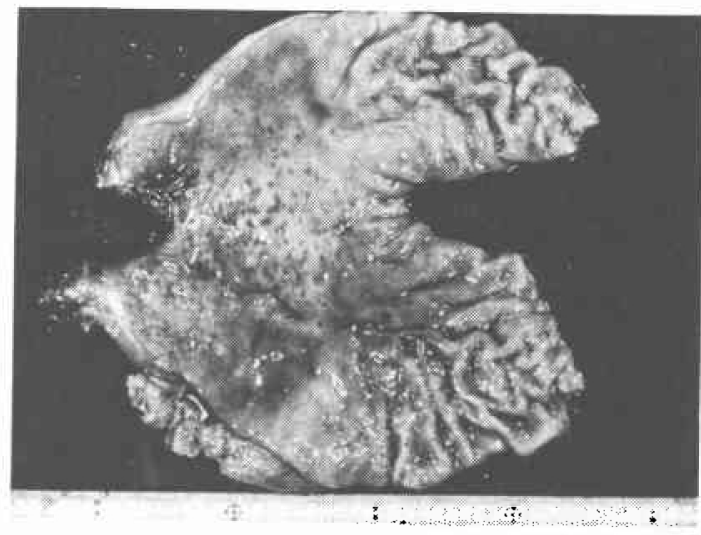

困2 肝転移巣組織写真。いわゆるカルシノイド腫汮 のA 型の像を呈する。

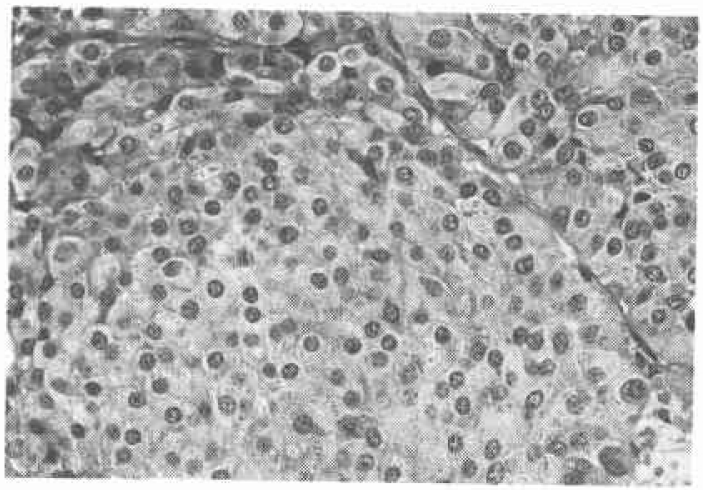

2).また，酵素抗体 PAP(peroxidase-antiperoxidase) 法にて, 胞体内に抗ガストリン血清に反応する多数の 微細顆粒が証明されガストリノーマと診断された(図 3 ).

術後 computed tomography (CT) 写真 : 膵頭部に 不均一な濃淡をもつ腫瘍陰影を認めた（図 4 ）.

術後経過：表 2 に示寸. 手術直後から,ファモチジ ン20mgを 1 日 2 回静注した. イレゥスの合併もなく, 第 3 病日には排ガスがみられた。しかし，留置胃管か らは, 白色透明の胃液が大量に排泄され続け, 第 7 病 日には胃管をいったん拔去したところ, 頻回の胃液呕 吐のため再挿入を余儀なくされている。第15病日には, 胃管からの血液の流出, タール便の排泄が認められ, 頻脈, 血圧低下を伴い, 残胃からの大量出血が示唆さ れた.このため輸血とともににファモチジンを $120 \mathrm{mg} /$ 日に増量し，持続投与とした $(0.16 \mathrm{mg} / \mathrm{kg} / \mathrm{hr})$ ところ， 
図 3 肝転移巣のガストリンに対する免疫組織学的染 色 (PAP法) 写真. ガストリン分泌顆粒が染色され ている.

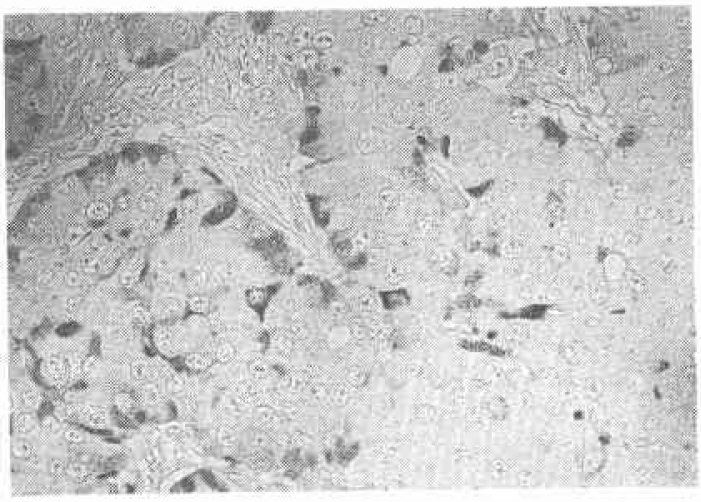

図 4 腹部 CT 写真. 術後にとられたもの. 膵頭部に 腫瘤陰影を認める。

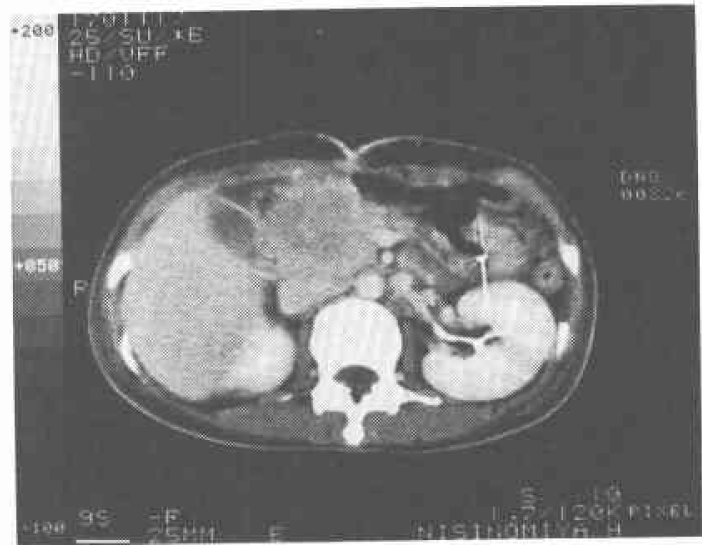

表 2 Z-E 症候群（胃切除術, 胃空腸吻合術術後経過 表） 47 歳，우

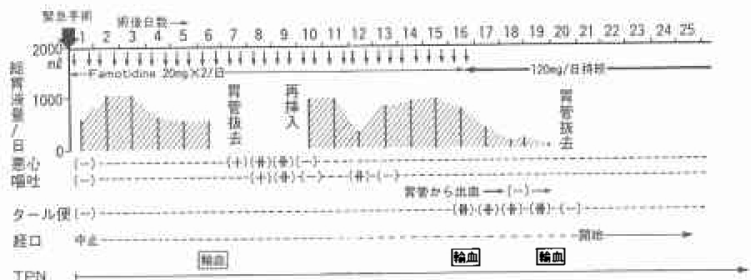

表 3 に示す上らに, 胃液分泌量の著減と止血が得られ た、第21病日から経口摄取を開始したが著変をみてい ない。な拈，この時点での基礎胃液分泌量 (BAO) は， $0.8 \mathrm{mEq} / \mathrm{hr}$ で, 胃酸分泌抑制は良好にコントロールさ れていると考えられた。第56病日からは，ファモチジ ン $120 \mathrm{mg} /$ 日を経口投与量として経過観察中である.

\section{考察}

1974年にFox らは，ZES での死因の多くは潰瘍に 基ゔくものであるとし，胃全摘を行った群とそうでな い群との生存率間に，明らかな有意差を認めたと報告 した2)、したがって, 肝転移巣を有するものや, 腫瘍病 変が広範で切除が不可能な場合に怙いても，姑息的手 術としての胃全摘を施行すべきであると述べてい $ろ^{2)}$.

しかし，欧米に拈ける一連の研究から ${ }^{7) 101212) ， Z E S ~}$ の酸分泌抑制に, $\mathrm{H}_{2}$-blocker が有効であることが証明

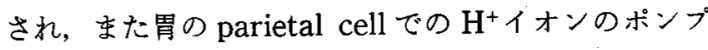
作用をブロックする omeprazole b酸分泌抑制に有効 であることがわかり ${ }^{13)}$, 近年 ZES に対する外科的治療 に，変遷がみられている，McCarthy ${ }^{14)}$ は， $\mathrm{H}_{2}$ blockerによる治療をルーチンとするだけでなく，腫 瘍切除により治癒する症例が非常に少いことから, 開 腹術すらもルーチンにすべきではないと述べている。

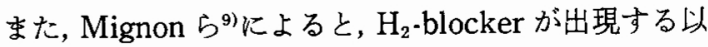
前（1959年から1974年までの ZES 症例）と比較した 1975年以後の症例では, “胃全摘とガストリノーマの切 除”といら古典的な術式が行われた頻度は，72\%から $28 \%$ に減少し，これに比例して，ガストリノーマに対 する単独手術施行頻度が有意に上昇したと報告してい る.

しかし，もちろん胃全摘が放棄された訳ではない。 Zollinger $5^{15)}$, Townsend $5^{4) 6)}$ は, $\mathrm{H}_{2}$-blocker に反応 しない症例があること, 長期大量投与に伴う副作用の 問題, 患者が内服をやめたために抗こる危険な合併症 や，内服治療のため悪性ガストリノーマに対する手術 時期を逸する危険性を考慮し，全身状態良好で患者が 手術拒否をしない場合, 胃全摘の価值は十分容認でき るものであるとしている。しかし，全身状態不良例や 緊急手術例での胃全摘は死亡率が高く, $\mathrm{H}_{2}$-blocker は，緊急手術を要するような合併症の予防と患者の全 身状態の改善により, 手術の安全性を高めるととるに, 診断の確定や他の内分泌腫瘍合併の検索を行う猶予を 与えてくれる点で有用であると述べている15).

本症例は, 全身状態不良な緊急手術を行い, 術後ファ モチジンの大量持続投与により, 酸分泌コントロール に成功したものである.

$\mathrm{H}_{2}$-blocker の投与方法はシメチジンを例にとると， NIH (National Institutes of Health) のシンポジウ ムで次のように決められている8).すなわち, 経静脈的 に $1 \mathrm{mg} / \mathrm{kg} / \mathrm{hr}$ から開始し，BAO が $10 \mathrm{mEq} / \mathrm{hr}$ 以下に 
なるまで 4 時間ごとに $0.5 \mathrm{mg} / \mathrm{kg} / \mathrm{hr}$ 増量する.もしシ メチジン量が 6 時間で $600 \mathrm{mg}$ 以上必要にな礼ば, 抗コ リン剤を併用する.しかし、この方法でも 1 日量が10 $\mathrm{g}$ 以上にも達する症例があり, このため vagotomyを

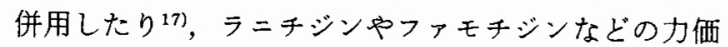
の高い $\mathrm{H}_{2}$-blockerを使用したり，また Omeprazol に 変更したりして, 副作用の予防と服用の煩雑さを防い でいる。

このよらに, 内服治療か胃全摘かの選択は, 一概に 論ずる訳にはいいかず，ガストリノーマのもつ生物学 的特徵5(8)915)187 患者の合併症や全身状態打よび quality of life 考虑した症例ごとの選択がなされる ベきであろう。

\section{おわりに}

潰漡底からの大出血のため緊急手術を余儀無くされ たZESの1例を報告した。肝転移を有し，また全身状 態不良であったため胃切除にとどめ, 酸分泌コント ロールルのためファモチジンを使用し，良好な経過を 得ることができた。

\section{文 献}

1) Zollinger RM, Ellison EH : Primary peptic ulcerations of th jejunum associated with islet cell tumors of the pancreas. Ann Surg 142 : $709-728,1955$

2) Fox PS, Hofman JW, Wilson SD et al: Surgical management of the zollinger-ellison syndrome. Surg Clin North Am $54: 395-407,1974$

3) Friesen SR: Treatment of the zollingerellison syndrome. Am J Surg 143 : 331-338, 1982

4) Thompson JC, Lewis BG, Wiener I et al: The role of surgery in the zollinger-ellison syndrome. Ann Surg 197: 594-607, 1984

5) Zollinger RM: Gastroinoma: Factors influencing prognosis. Surgery $97: 49-54,1985$

6) Norton JA, Collen MJ, Gardner JD et al: Prospective study of gastroinoma localization and resection in patients with zollinger-ellison syndrome. Ann Surg $204:$ 468-479, 1986

7) McCarthy DM: Report on the United states experience with cimetidine in zollinger-ellison syndriome and other hypersecretory status. Gastroenterology $74:$ 453-458, 1978

8) Jensen RTM, Gardner JD, Raufman JP et al : Zollinger-ellison syndrome: Current concepts and management. Ann Int Medicine 98 : $59-75,1983$

9) Mignon M, Ruszniewski P, Haffar $S$ et al : Current approach to the management of tumoral process in patients with gastrinoma. World $\mathrm{J}$ Surg 10:703-710, 1986

10) Bonfils S, Mignon M, Gratton J: Cimetidine treatment of acute and chronic zollingerellision syndrome. World J Surg $3: 597-604$, 1979

11) Friesen $S R$, Hermreck $A S$, Brackett $C E$ et al : Cimetidine in the management of synchronous crises of MEA 1. World J Surg 4:123-129, 1980

12) Malagelada JR, Edis AJ, Adson MA et al: Medical and surgical options in the management of patients with gastrinoma. Gastroenterology $84: 1524-1532,1983$

13) McArthus KEM, Collen MJ, Mation PN et al : Omeprazole: Effective, convenient therapy for zollinger-ellison syndrome. Gastroenterology 88: 939-944, 1985

14) McCarthy DM: The place of surgery in the zollinger-ellison syndrome. N Engl J Med 302 : 1344-1347, 1980

15) Zollinger RM, Ellison EC, O'Dorisio TM et al: Thirty years experience with gastrinoma. Worl J Surg 8: 427-432, 1984

16) Townsend CM, Thompson JC: Gastrinoma. Surg Clin North Am $66: 695-712,1986$

17) Richardson CT, Peters MN, Feldman $M$ et al : Treatment of zollinger-ellison syndrome with exploratory laparotomy, proximal gastric vagotomy and $\mathrm{H}_{2}$-receptor antagonists prospective study. Gastroenterology 89 : 357-367, 1985

18）今村正之, 嶋田 裕, 内藤元康ほか：選択的動脈内 セクレチン注入試験により局在が診断されて根治 切除しえた悪性 microgastrinoma。膵臓 1；96 $-101,1986$ 